\title{
Once Again about Dostoevsky's Response to Hans Holbein the Younger's Dead Body of Christ in the Tomb
}

Robert Louis Jackson

Ma qui la morta poesì resurga,

o sante Muse, poi che vostro sono.

-Dante, Purgatorio 1:7-8

I begin my discussion of Dostoevsky's response to Holbein's Dead Body of Christ in the Tomb ${ }^{1}$ with some commentary by St. Augustine in his Confessions ${ }^{2}$ on the problem of formed formlessness.

Augustine's discussion turns on the first two lines of Genesis: "In the beginning God created the heaven and the earth. But the earth was invisible and without form, and darkness was upon the deep." ${ }^{3} \mathrm{He}$ accepts the notion that "before the Lord formed this unformed matter and fashioned it into kinds,

1 Henceforth in the text I refer to Holbein's painting as (The) Dead Christ.

My earliest discussion of Dostoevsky and Hans Holbein the Younger's painting The Dead Christ in the Tomb (Der Leichnam Christi im Grabe, 1521/1522) may be found in my study, Dostoevsky's Quest for Form: A Study of His Philosophy of Art (New Haven, CT: Yale University Press: 1966), 66-69 et passim. I returned to my discussion of Holbein and Dostoevsky in a paper at the symposium of the International Dostoevsky Society in Naples, Italy, in 2010.

2 Dostoevsky mentions Augustine's Confessions in his notebook for 1875-76. See Polnoe sobranie sochinenii $v$ tridtsati tomakh [PSS], ed. V. G. Bazanov et al. (Leningrad: Nauka, 1972-90), 27:113n; hereafter cited as PSS by volume and page.

3 The Russian Slavonic Bible translates the first line of Genesis as Zemlia že bè nevidim $i$ ne ustroen ("But the earth was invisible and unformed"). 
there was no separate being, no color, no shape, no body, no spirit," that is, there was only the earth "unformed." He insists, however, that "there was not absolutely nothing"; rather "there was a certain formlessness devoid of any specific character."

"Formlessness" for Augustine, then, is not nothing, but something. Yet he is bothered: "Why," he asks the Lord, "may I not perceive that the formlessness of matter which you made without beauty, but from which you made this beauteous world, is effectively indicated when called "'earth invisible and without form'?"s

Augustine's dilemma is plain: the moment he tries to perceive or conceive formless matter, he comes up with forms, that is, with embodiments of formlessness that are unsatisfactory precisely because they are forms or images. The issue for him is not only aesthetic but also ethical and spiritual:

I formerly conceived [the formlessness of matter] as having countless different forms, and therefore I did not conceive it at all. My mind turned over forms, foul and horrid in confused array, but still forms. I called it formless not because it lacked all form, but because it had such form that, if it ever showed itself, my senses would have turned away from it as from something strange and improper, and man's frail powers would be disturbed by it. But what I was thus thinking about was formless not from lack of all form, but by comparison with better formed things. ${ }^{6}$

Augustine's discussion does not end here. I would like to rest, however, with his posing of the problem of formless form and his distinction between lesser and better formed things, a notion essentially of two kinds of beauty. ${ }^{7}$

\section{2}

The question of two kinds of beauty, essentially that of formless form, turns up in an exchange between Anna Grigorievna Dostoevsky and Fyodor Mikhailovich Dostoevsky on the occasion of their viewing of Holbein's

4 See The Confessions of St. Augustine, trans. with an introduction and notes by John K. Ryan (Garden City, NY: Doubleday, 1960), 12.3, p. 306.

5 Ibid., 12.4, p. 306.

6 Ibid., 12.6, p. 307.

7 Augustine earlier in Confessions formulates his concept of two kinds of beauty when, in connection with his youthful interest in the pleasures of the flesh, he distinguishes between "lower beauties" and "lower goods," on the one hand, and "lower beautiful creatures" and creatures of "grace and beauty," on the other: "Do we love anything except that which is beautiful? What then is a beautiful thing? What is beauty?" (ibid., 4.13, p. 106). 
painting The Dead Christ in the Historisches Kunstmuseum in Basel, Switzerland, on August 12, 1867.

In her stenographic Diary for this date, Anna Grigorievna contrasts her own view of Holbein's Dead Christ with Dostoevsky's response to that work. "This astonishing work simply filled me with horror," she writes, "but Fedya was so struck by Holbein's Dead Christ that he proclaimed Holbein a remarkable artist and poet." (a Fediu tak do togo porazilo, chto on provozglasil Gol'beina zamechatel'nym khudozhnikom i poetom). Like Ippolit Terentiev in Dostoevsky's The Idiot (1868-69), though without his spiritual turmoil, Anna Grigorievna contrasts the usual classical representation of Christ's body —one without marked wounds or lacerations - with what she regards as Holbein's repulsive, albeit well-executed, depiction of Christ's crucified body. She goes on to describe in detail the horrible mutilations inflicted on Christ's body, concluding that Holbein's dead body of Christ so strikingly "resembled an actual corpse that, really, I would not have wanted to be in the same room with it."

"Granted that all this has striking verisimilitude," she writes, "but really it is not at all esthetic ${ }^{8}$ [no, pravo, eto vovse ne estetichno] and aroused in me nothing but revulsion and a kind of horror." And for the second and final time in her Diary account, Anna Grigorievna underscores Dostoevsky's strong dissent: "Fedya, however, was ecstatic over this painting" (Fedia zhe voskhishchalsia etoi kartinoi). "Wanting to examine it more closely," she concludes, "[Dostoevsky] stood on a chair to examine it, and I very much feared that he would be fined for it."

Dostoevsky's words, "a remarkable artist and poet," constitute the highest praise he could offer any painter or writer. The word "poet" is sacred in his vocabulary. It embodies not only the notion of inspiration, but of imagination and insight, vision and prophecy, elements central to his concept of fantastic realism. Implicit, then, in his initial response in Basel to the Dead Christ is a conception of realism and reality as multidimensional and of an aesthetics of form and beauty as more inclusive than classical beauty, even as the highest Beauty, the beauty of Christ remains for him transcendent and an ever unattainable ideal.

8 The phrase ne estetichno suggests also "tasteless."

9 A. G. Dostoevskaya, Dnevnik (1867), ed. S. V. Zhitomirskaya (Moscow: Nauka, 1993), Basel, Thursday, August 12 [new style: August 24], 1867. 
As his dramatization in The Idiot of Holbein's Dead Christ attests, Dostoevsky posits in Holbein's painting a powerful and complex spiritual pro and contra. His response to Holbein's Dead Christ in Basel, however, is of signal importance in that it underscores the aesthetic and spiritual point of view that underlies his employment of Holbein's Dead Christ in the apocalyptic universe of The Idiot.

Forty years after viewing Holbein's Dead Christ in Basel, Anna Grigorievna Dostoevsky returns to the topic of her husband's response in Basel to Holbein's Dead Christ. In her posthumous Reminiscences (1925), Anna Grigorievna, ignoring entirely her earlier Diary account in 1867 of Dostoevsky's affirmative response to Holbein's Dead Christ, now speaks of the "devastating impression" (podavliaiushchee vpechatlenie) that Holbein's painting made upon Dostoevsky: he stood before it "as though stunned"; she recalls her concern that Dostoevsky might have had one of his epileptic fits. ${ }^{10}$ In one of her notes to the 1906 edition of The Idiot, referring to the page where Prince Myshkin remarks that "a person looking at this [Holbein's] painting could lose his faith," Anna Grigorievna recalls that Dostoevsky was "terribly shaken up" by Holbein's painting, adding that "at that time" he "told me that 'a person looking at this painting could lose one's faith." "Later in life," she writes, "Dostoevsky would often recall the terrible impression this painting made upon him." ${ }^{11}$

There can be no doubt that Holbein's Dead Christ made a tremendous impression on Dostoevsky, but why did Anna Grigorievna completely ignore her Diary account in 1867? Did she conflate Dostoevsky's response to the Dead Christ with Ippolit Terentiev's critique of Holbein's painting? Her unwillingness or inability to reconcile her later account of Dostoevsky's reaction to Holbein's Dead Christ with her earlier one suggests not only her own personal bias, but a misunderstanding of art and of an author's relation to his characters. In any case, her later recollections combine with her earlier ones to underscore

10 See A. G. Dostoevskaya, Vospominaniia (Moscow: Izdatel'stvo "Pravda," 1987), 185-86. See also the English version of these recollections, Dostoevsky: Reminiscences, trans. and ed. Beatrice Stillman, with an introduction by Helen Muchnic (New York: Liveright: 1975), 133-34.

11 Cited in L. P. Grossman, Seminarii po Dostoevskomu: Materialy. Bibliografiia i kommentarii (Moscow-Petrograd: Gosizdat, 1922), 59. 
Dostoevsky's deep and intense involvement with the great pro and contra Holbein's Dead Christ in his novel, The Idiot. ${ }^{12}$

\section{3}

Dostoevsky's writings and criticism in the period following his return from Siberia foreground important concepts of realism and reality that he brought to his interpretation and understanding of Holbein's Dead Christ. Central here is the distinction he repeatedly draws between natural or actual truth and artistic truth in the fine arts and in writing. In a harsh review of the Russian painter Valery I. Jacobi's Prisoners at a Stopping Place (Prival arestantov, 1861), exhibited at a St. Petersburg Academy of the Arts exhibition in 1861, Dostoevsky agrees that the painting's representation of the scene is "exact as it is in nature ... if you look at nature, so to speak, only from the outside, as though you were looking in a mirror or photograph." Yet this simply "attests to the absence of art." There is absolutely no "truthfulness" in Jacobi's painting, Dostoevsky declares. This is not "reality," but a "lie." Of course, he concedes, the artist must know the ABC's of reality, but he "first of all must overcome the difficulties of transmitting actual truth in order to rise to the heights of artistic truth." 13

This principle of realism was not new to Dostoevsky, but it was one that acquired a deep spiritual and populist meaning for him during his years of trial and prison and exile in Siberia. He embodied this principle in his semi-autobiographical Notes from the House of the Dead (1861-62). In this work he depicts the brutal existence of prison convicts, but at the same time sees through what he calls the "repulsive crust" of their condition to their intrinsic humanity. The accomplishment of Notes from the House of the Dead, a triumph of artistic and spiritual truth over natural truth (though without concealing the horrendous reality of prison

12 Take, for example, these lines from one of Dostoevsky's early plans for his novel when the Idiot, in a conversation about Christ's moment of despair on the cross ("The passion on the cross shatters the mind"), calls attention to Christ's "terrible cry." "What cry?" his interlocutor asks. "Eloi! Eloi!" "So there was an eclipse." "I don't know—but it was a terrible cry," the Idiot answers. Dostoevsky directly follows this exchange with the line: "The story of Holbein's 'Christ' in Basel” (PSS, 9:184).

13 PSS, 19:154. 
life) was the restoration of the image of the wounded and disfigured image of the Russian people.

Dostoevsky found in the writing of Victor Hugo an aesthetic-spiritual outlook congenial to his own. In a preface to the publication in 1862 of a translation of Hugo's Hunchback of Notre Dame (Notre Dame de Paris, 1831) ${ }^{14}$ Dostoevsky defends the French writer against the charge that his aesthetic method could be summed up in the phrase Le laid, c'est le beau- "ugliness is beautiful." Hugo's basic idea, a "Christian and supremely moral one," was the "restoration of fallen man"; Hugo's so-called monster, the deformed but kindly Quasimodo, is for Dostoevsky the embodiment of the "oppressed and despised, dumb and disfigured" (glukhogo i obezobrazhennogo) French people of medieval times "in whom there is an awakening of love and a thirst for justice."

Hugo's aesthetics of "beauty and ugliness" early entered Dostoevsky's own stream of aesthetic thought. At the age of seventeen he had read Hugo's groundbreaking Préface de Cromwell (1827). ${ }^{15}$ Hugo wrote there,

The division of the beautiful and ugly is not symmetrical with that of nature. Nothing is beautiful and ugly in the arts except through execution. An ugly horrible, hideous thing, transported with truth and poetry into the realm of art, becomes beautiful, admirable, without losing anything of its monstrosity.

Hugo's observations broadly anticipate Dostoevsky's response to Holbein's painting in Basel. The Romantic aesthetic of another writer, the English poet John Keats, opens up pathways to an understanding of Dostoevsky's reception of Holbein's Dead Christ and his realism. In a letter to his two brothers in 1817, Keats remarks of the Anglo-American painter Benjamin West's painting, Death on a Pale Horse: "It is a wonderful picture, but there is nothing to be intense upon.... The excellence of every Art is its intensity, capable of making all disagreeables evaporate from their being in close relationship with Beauty and Truth. Examine King Lear and you will find this exemplified

14 PSS, 20:28-29.

15 In a letter to his brother Mikhail, August 9, 1838, Dostoevsky mentions Hugo's Cromwell as part of his reading; see PSS, 28(1):51. 
throughout: but in [West's] picture we have unpleasantness without any momentous depth of speculation." ${ }^{16}$

Keats's idea of "burying" "disagreeables" does not at all mean eliminating them from a work of art. What he looks for, and finds in Shakespeare, and what Dostoevsky found in Holbein's Dead Christ and dramatized in The Idiot, was an intensity and momentous depth of speculation, a pro and contra, that put the work in close relationship to the highest aesthetic and spiritual values.

What Dostoevsky found in The Dead Christ he did not find in Mikhail P. Klodt's The Last Spring (Posledniaia vesna, 1861), a Gold-Medal painting in the Academy of Arts exhibition in 1861. In his review of this exhibition, Dostoevsky sharply condemns The Last Spring, along with Jacobi's Prisoners at a Stopping Place, for its naturalism. Death is at the center of the painter's attention: "The Last Spring depicts a dying young woman in a chair, looking sadly towards a window opening onto a bright spring day." The painting is "a remarkable one," Dostoevsky comments, the "whole painting is beautifully painted, but as a whole," he remarks abruptly, "the painting is far from beautiful. Who wants to hang such a pathological painting in his office or living room? It goes without saying, nobody, nobody." Nobody, he exclaims, needs this "poisonous" "perpetual memento mori." "Taken by itself death is a repulsive business. But waiting for death is far more repellent. The artist has chosen for himself an extraordinarily difficult task: nobody will ever succeed in representing the repulsive in a beautiful way."

Dostoevsky allows that there are "dramatic works that represent dying on the stage," but he argues that one cannot depict a dying person on the stage "according to all the rules of pathology, systematically conveying natural truth as it happens in nature." Dostoevsky illustrates his point by offering a verbal sketch of a dying person who sits up, gazes about and "rolls his eyes like a bad provincial actor playing Othello." An audience, he argues, "would rush away from such a performance." But Mr. Klodt, he continues, presents us with the

16 Letter of John Keats to his brothers George and Thomas, December 28, 1817; see John Keats, Complete Poems and Letters, ed. Clarence DeWitt Thorpe (New York: Doubleday, Duran \& Co., 1935), 527-28. In the same letter, Keats amplifies on the quality he finds Shakespeare's achievement: "I mean Negative Capability, when a man is capable of being in uncertainties, Mysteries, doubts, without any reaching after fact and reason" (ibid.). In a certain sense we can speak also of Dostoevsky's Negative Capability with respect to his dramatization of Holbein's Dead Christ in The Idiot. 
agony of a dying person and the agony of a whole family not just for one day or for a month but "eternally, as long as that beautifully executed, but unfortunate painting hangs on the wall." "No," Dostoevsky concludes, "artistic truth is not that at all, it is something quite different from natural truth." ${ }^{17}$

Whatever the shortcomings of Mikhail P. Klodt's painting, it is not "pathological” in character. Rather, Dostoevsky's angry and agitated response to the Last Spring touches on the pathological. Contemporaneous with his review, he was publishing his semifictional recollections of House of the Dead: a world where a fatalistic waiting for death, on the one hand, and rebellion of all sorts against the fatality of prison life, on the other, marked everyday existence. Klodt's "picture on the wall" plunged Dostoevsky back into the pathos and pathology of the prison world. He found no higher spiritual truth in Klodt's painting, no hint of anything beyond the "last spring," only "natural truth," a perpetual reminder of death as doom.

In Dostoevsky's review of The Last Spring, finally, one hears the irascible and strained voice of his Underground Man as he will lash out at the so-called wall in Notes from Underground (1864): "Twice two is four, gentlemen, is not life, but the beginning of death." We hear too Dostoevsky's irascible voice-the voice of the critic of The Last Spring - in the near hysterical response of Ippolit Terentiev to Holbein's Dead Christ-a work, in Ippolit's view, that depicts "nature" crushing a "great and precious being." Yet throughout his depiction of Ippolit's rebellion we also hear in the subtext Dostoevsky's critique of a man, Ippolit, who has suffered a crisis of aesthetics and faith and cannot break through to a broader aesthetic and spiritual vision.

\section{4}

The phrase "two kinds of beauty," or, more exactly, "two nice kinds of beauty," turns up in Dostoevsky's notebook on The Idiot a little more than six months after he saw Holbein's painting in Basel. The use of the diminutive obrazchika signals irony in the question Ippolit puts to Prince Myshkin shortly before he, Ippolit, begins to read his "necessary explanation": "Is it true, Prince, that you said 'beauty' will save the world? ... What kind of beauty will save the world?"18

17 PSS, 19:167.

18 PSS, 8:317. 
Myshkin has in mind higher beauty, the beauty and perfection of Christ. Ippolit has in mind Holbein's representation in his painting of the disfigured body of Christ, a depiction in which he finds "not a trace of beauty." "What kind of beauty will save the world?" That question, and its implicit challenge to faith, is at the core of Ippolit's critique of Holbein's Dead Christ. He in general finds "nothing good about it in artistic respects" ( $v$ nei ne bylo nichego khoroshego $v$ artisticheskom otnoshenii) — a fact of significance. ${ }^{19}$ Yet his feeling of "strange unrest" (strannoe bespokoistvo) on looking at The Dead Christ indicates that Holbein's painting has struck a spiritual chord in his memory. In looking at this painting it seems to Ippolit as if "nature" in the form of some "huge, implacable and dumb beast" or "huge machine" had senselessly seized, torn up, and devoured "a great and precious being," such a one who was "worth the whole of nature, its laws, and the whole earth which perhaps was created solely for the appearance of this being alone!" It is noteworthy that in his telling, Ippolit does not name this "precious being," does not utter the word "Christ," as he does elsewhere; nor does he in any way see or visualize the image, or obraz, of Christ, that is, he experiences no epiphany, no sense of Christ's presence or perfection. Rather he experiences Christ as something precious that has been lost, as something that remains as a "tremendous thought." What he does directly see, however, is the disfigured body of Christ in Holbein's painting.

\section{5}

It is a fact of Ippolit's character, of Dostoevsky's characterization of him, that in his egoism and intellection he is to a large extent unaware or unconscious of the latent spirituality within him. He is unaware that he carries within the idea of love and self-sacrifice; he does not know that he is imitating Holbein's Christ when he lies down, eyes wide open and focused on the icon at the foot of his bed. He is like Columbus, Dostoevsky suggests, a man who had discovered America, but without knowing it. Ippolit will never pass over the threshold of egoism to belief. Nonetheless, he has a keen and telling, indeed tormented, interest, in the crisis of aesthetics and faith.

19 PSS, 8:338-39. Here, of course, is the fault line separating Ippolit's view of Holbein's painting from Dostoevsky's. The failure of Ippolit to see Holbein's painting as a work of art and poetry is correlative in Dostoevsky's view with his failure to recognize, on the conscious plane at least, the spiritual action of the painting. The crisis of faith is inseparable for Dostoevsky from the crisis of aesthetics. 
Of great interest in this connection are his brief reflections on the terrible impact the disfigured and crucified body of Christ must have had on his disciples and followers. Noteworthy in his discussion is his use of the Russian word obraz - "image, form, icon, beauty," ${ }^{20}$ in the highest sense of the word, the imago Dei or perfect image of Christ of Orthodox tradition; its counterpart is bezobrazie-literally, that which is "without image," i.e., the misshapen, the deformed, the scandalous, the ugly. Christ suffered not figuratively, but in actuality (Khristos stradal ne obrazno, a deistvitel'no), Ippolit remarks: "If precisely such a corpse had been seen by his disciples and apostles; if it had been seen by women who had followed after him and stood by the cross, who had believed in him and worshipped him, then how [kakim obrazom; literally, "with what kind of image before them"] could these people, on looking at that corpse, have believed that this sufferer would resurrect?" In short, how could they retain faith in the Resurrection in the presence of the totally disillusioning actuality of a brutally disfigured Christ? ${ }^{21}$

20 ' 'Obraz' has been called the 'axis of beauty' in the Russian language"- "L'image, dans la langue russe, est l'axe de la Beauté." See Lydie Krestovsky, La laideur dans l'art a travers les ages (Paris: Editions du Seuil, 1947), 36.

21 The crisis of aesthetics and faith is tersely dramatized with respect to dead bodies of family kin - though not, at least overtly, with regard to the dead body of Christ in the tomb-in one of the liturgical verses sung on Trinity Parental Saturday (Troitskaia roditel'skaia subbota) or All-Souls Day, the Eastern Orthodox church service commemorating the family dead):

I weep and sob when I picture death and see lying in the tombs, disfigured, inglorious, without any form, our beauty created in the image of God. O, miracle! What is this mystery that was performed over us? How were we given over to corruption? How were we joined with death? Verily, by the will of God, as is written, giving us the rest that was presented to us.

Пиачу и рыдаю, / когАа себе преАставлю смерть / иувижу в гробницах межащую / по образу Божию созданную нашу красоту / безобразной, бесславной, не имеющей вида. / О чудо! / Что это за совершившееся над нами таинство? / Как мы были преАаны тиению? / Как сочетались со смертью? / Воистину повемением Бога, как написано, / подающего преставившимся упокоение.

The singer here pictures the disintegration and decay of the bodies of kin, "our beauty created in the image of God," lying in the tomb. He does not speak of shaken faith, but his weeping and sobbing, his leap to "miracle," his agitated questions, suggests a subtext of spiritual anxiety, and a sense of the poverty of words before the sight of disfigured (bezobraznye) bodies of loved ones in the tomb. It is no accident that this verse is followed by one that offers a reassuring verbal picture of joyous family reunion in heaven.

I thank Olga Meerson of Georgetown University for drawing my attention to this liturgical verse. 
Ippolit has projected his own crisis of aesthetics and faith onto the followers of Christ. He brings the whole matter to a head with his question, "Can one perceive in an image that which has no image?" (Mozhet li mereshchit'sia $v$ obraze to, chto ne imeet obraza?). The question alludes in part to his own despairing response to Holbein's painting: his delirious dreams where he has seen monstrous things. Like Augustine, he is troubled by "strange, impossible form"; he sees all sorts of terrible, unimaginable, so to speak, un-image-able things "even in images." On the other hand, the notion of "a great and precious being" arises in his consciousness as he rages against Holbein's painting. In this context Ippolit's question falls into the same category as the one that perplexed Augustine: Why could he, Augustine, not visualize the beauteous world that the Lord had created out of formless matter?

Ippolit's question may thus be rephrased: Can one perceive obraz (the "highest beauty," the "perfection" of Christ) in bezobrazie, that which is "without image," in short, ugly, monstrous, disfigured? The answer, in Russian, is hidden in plain view. Obraz is the central, indestructible component of bezobrazie. Ippolit will never internally visualize his ideal, aesthetically and spiritually. As Dostoevsky wrote in his review of Jacobi's painting: "In ancient times they would say that the artist must see with physical eyes and, above all, with eyes of the soul, or with a spiritual eye."22 Ippolit lacks that kind of "eye." Yet in looking at Holbein's painting he experiences a shock: a collision between his residual ideal, (the "great and precious being") and the reality of a world-historic violation of that ideal, a collision between purity and pollution, form and disfiguration, obraz and bezobrazie.

"Les extrêmes se touchent" ("opposites meet"), Ippolit remarks with reference to himself and Rogozhin shortly after viewing a reproduction of Holbein's Dead Christ in Rogozhin's house and before Rogozhin describes the impact Holbein's painting had upon him. Ippolit's words evoke the ancient philosophical concept of the unity of opposites; they speak of an unconscious awareness of the paradoxically affirmative action the pro and contra of Holbein's Dead Christ.

Can one perceive obraz in bezobrazie? Can one perceive the highest beauty in the utmost darkness and degradation? "The need for beauty and the creation

22 PSS, 19:54. 
which it embodies," Dostoevsky wrote in "Mr. -bov and the Question of Art” (1861) not too long after his return from prison and exile, "is inseparable from man, and without it man, perhaps, would not want to live in the world.... The need for beauty develops most at the moment man is in discord with reality, in disharmony, in struggle. ... In beauty there is both harmony and tranquility." ${ }^{23}$

These thoughts, on the personal plane, echo the profound and transforming spiritual crisis of Dostoevsky in his prison years. On his release from prison in Omsk in January 1854, he writes in a letter to Natalia D. Fonvizina of his sufferings there and of how at moments he would "thirst for faith, like withered grass and find it exactly because truth dawns in misfortune [ $v$ neschast'e iasneet istina]." This "thirst to believe grows all the stronger in my soul the stronger the opposing arguments." In "moments of complete tranquility," Dostoevsky writes, he would "compose his symbol of faith": that "there was nothing more beautiful, profound ... and perfect than Christ." ${ }^{24}$

The concept of a basic need in man for beauty, a longing for something to venerate, on the one hand, and of truth, beauty, faith emerging in misfortune, struggle, disharmony, in discord with reality, on the other, is at the heart of Dostoevsky's understanding of Holbein's Dead Christ in The Idiot, of its action, of its pro and contra, of the spiritual movement it arouses in the viewer. There is no final outcome of this action, no grand synthesis and new thesis. Dostoevsky predicts nothing, but he promises movement, "Les extrêmes se touchent." Rogozhin, reflects Myshkin, "says that 'he likes to look at this painting'; he doesn't; rather it seems, he feels a need .... he wants to get back his lost faith by force. ${ }^{25}$ He needs it now to the point of torment. Yes! to believe in something! to believe in somebody!" Myshkin utters these last words as though grasping some new thought; indeed, he appears to have broadened his understanding of the impact of the Dead Christ. "But still," he reflects, as though another thought had entered his head, "how strange this painting is." Myshkin does not elaborate. Is he thinking about the pro and contra of Holbein's Dead Christ? Myshkin, as we know, declares

23 PSS, 18:94.

24 PSS, 28(1): 176.

25 For Dostoevsky, of course, "force" is not a path to faith, as it is not a solution in human relations, a fact that is all too evident in the denouement of Rogozhin's relation to Nastasya Filippovna. 
that "some people could lose their faith in looking at this painting." "Some people"-but not everybody. Again, Myshkin does not elaborate on this point. Ippolit Terentiev experiences a feeling of "strange unrest" on looking at Holbein's Dead Christ.

A sense of permanent unrest and unease, bad dreams, and endless imaging of, and striving for, the unattainable ideal-here is where Dostoevsky leaves us.

\section{6}

Early on in the The Idiot, Prince Myshkin remarks: "I dare say I am indeed a philosopher, and who knows, perhaps, and in real fact, I have the thought of teaching." In one of his studies, Leonid Grossman suggested that Dostoevsky planned to include in The Idiot an interpretation by Prince Myshkin of Holbein's Dead Christ: "Questions of atheism and faith, realism and naturalism would have occupied a big space." ${ }^{26}$ Dostoevsky plainly concluded that such a broad discussion from above, accompanied by aesthetic and spiritual self-awareness from below, would be inconsistent with his development of the character and fate of Myshkin in his apocalyptic novel. Whatever the reasons, Dostoevsky canceled Myshkin's lecture, leaving it to us to ponder again, and again, the great questions surrounding his response to Holbein's Dead Christ in Basel in 1867 and his dramatic employment of the painting in The Idiot.

26 Leonid Grossman, Dostoevskii (Moscow: Molodaia gvardiia: 1962), 405-6. 
